\title{
Kualitas Pemimpin Sebagai Pendidik Dalam Menghadapi Konflik
}

\author{
Maidiantius Tanyid \\ Sekolah Tinggi Agama Kristen Negeri Toraja \\ tanyid@gmail.com
}

\begin{abstract}
The leader is the person whom is responsible to ensure all the task will be done. Therefore the leader needs to delegate those tasks for each person that was considered has some competences. A leaders as an educator must be able to carry out leadership base on the truth of God which always educate and motivate the team work. Being a leader who able to educate or as educator who can lead is two resposibilities those cannot be separated. Because the leader as an educator must be able to demonstrate their integrity based on truth.
\end{abstract}

Keywords: leader, educator, basic quality

\begin{abstract}
Abstrak: Pemimpin merupakan orang yang bertanggung jawab melakukan tugas, dan tugas itu dipercayakan kepada setiap bawahan yang dianggap dapat bertanggungjawab melakukannya sesuai dengan kompetensi. Pemimpin sebagai pendidik adalah pemimpin yang mampu menjalankan kepemimpinan dengan berstandar kebenaran, mendidik dan memotivasi. Menjadi pemimpin yang mampu mendidik dan pendidik yang dapat memimpin, dan dua kata penting yaitu "pemimpin dan pendidik" tidak dapat dipisahkan dalam menjalankan tanggungjawab. Pemimpin yang mampu menjalankan tanggung jawab sebagai pemimpin sekaligus menjadi pendidik adalah pemimpin yang mampu menunjukkan integritasnya berdasarkan kebenaran.
\end{abstract}

Kata-kata kunci: pemimpin, pendidik, kualitas dasar

\section{A. Pendahuluan}

Pemimpin sebagai pendidik merupakan pribadi yang memiliki peran utama sebagai pemimpin yang mampu menjadi pendidik untuk mendewasakan. Dari peran tersebut, menunjukkan bahwa sesungguhnya pemimpin mempunyai tugas rangkap dalam pelayanan yaitu mempimpin dan mendidik. Sebuah statement yang menginspirasikan berbunyi, "Seorang pemimpin harus mampu mendidik dan seorang pendidik harus bisa memimpin." Pemimpin pendidik dalam hal ini seorang pemimpin Kristen yang sungguh-sungguh mengerti bahwa panggilan Allah adalah amanat yang harus dikerjakan. Oleh karena itu, ia memerlukan kesiapan yang matang dalam melaksanakan tugas dan mental yang kuat dalam menghadapi pergumulan dalam kehidupan kepemimpinan. Beberapa pergumulan pemimpin di lapangan menunjukan bahwa pemimpin membutuhkan kualitas dasar agar siap sebagai pemimpin pendidik, baik secara akademik, ketrampilan, maupun mental. Hal ini dimaksudkan agara sang pemimpin mampun menghadapi berbagai tantangan dalam kepemimpinan masa kini. Pemimpin sebagai pendidik menjadi pribadi yang dapat diteladani di berbagai aspek kehidupan; baik menyangkut aspek spiritual, moral, 
sosial, tindakan, pengalaman, gaya kepemimpinan dan berbagai hal yang berhubungan dengan kinerja kepemimpinan.

Pemimpin sebagai pendidik hendaknya memiliki pemahaman mengendai dasardasar kepemimpinan baik secara teologis, filosofis, maupun sosiologis. Pemimpin dituntut mampu memiliki karakteristik yang membedakannya dengan orang lain. Dari perspektif spiritual misalnya, yang bersangkutan harus mampu menampilkan diri sebagaimana nilai-nilai religius yang diyakininya. Dari segi pengetahuan, yang bersangkutan diharapkan memiliki wawasan yang luas, yang didapatkannya baik melalui jalur pendidikan formal, maupun informal ataupun autodidak. Jelasnya seorang pemimpin harus mencintai proses belajar yang berkesinambungan, dalam setiap waktu dan kesempatan sampai pada akhir hidupnya. Kepemimpinan juga tidak dapat dipisahkan dari fungsi manajerial, adapun elemen-elemen mendasar yang harus dimiliki adalah visioner, perencana, organisator pelayanan, pelaksana pelayanan, pengendali pelayanan, berpengaruh dan terus mengadakan evaluasi terhadap apa yang telah dikerjakannya. Dari segi modal sosial, rasa tanggungjawab yang tinggi terhadap panggilan Allah harusn diwujudkan secara aplikatif kepada warga yang dipercayakan Tuhan untuk dipimpinya. Oleh sebab itu, Pemimpin sebagai pendidik akan membawa pengaruh yang positif, menjadi alat yang berguna dalam pelayanan dan mampu melaksanakan pengajaran Firman Tuhan yang benar. Namum hal-hal tersebut sering terabaikan, sehingga orang yang dipimpin sulit menjadi dewasa secara rohani. Myron Rush menjelaskan bahwa:

Para pemimpin yang berhasil, mempedulikan nasib orang lain. Para pemimpin yang berhasil mempunyai keyakinan pribadi yang kuat yang menjadi tuntutan hidup. Pemimpin yang berhasil sanggup merekrut orang lain dalam usaha memperjuangkan mereka. Pemimpin yang berhasil memberi tantangan kepada orang lain agar mampu melakukan hal yang terbaik. Pemimpin yang berhasil mengetahui cara melatih orang lain. Pemimpin yang berhasil mengetahui saat yang tepat untuk menghentikan kerisuhan dan membiarkan orang lain memimpin secara mandiri. ${ }^{1}$

Pemimpin dan pendidik menyentuh soal integritas yang sangat erat hubungannya dengan kepribadian sebagai Pemimpin sebagai pendidik dan hal ini sangat menunjang dalam pembinaan dan pengajaran terhadap pendewasaan orangorang yang dipimpinnya. Banyak pemimpin yang pintar berkhotbah dan mengajar tetapi ditolak karena kepribadiannya tidak menunjukkan integritas yang sesuai. Andre Bustanoby, mengatakan, bahwa: "Kepribadian lebih berharga dari pada kekayaan karena seseorang tidak bisa dibeli dan di bayar dengan uang. Kekayaan bisa hilang dengan sekejap tetapi kepribadian meninggalkan bekas yang tak muda dilupakan."2

Persoalan yang mungkin dihadapi oleh setiap Pemimpin sebagai pendidik, yang memberikan pengaruh dalam menjalankan kepemimpinannya adalah: Pertama, sesungguhnya Pemimpin sebagai pendidik mempunyai tugas rangkap dalam pelayanan, tetapi Pemimpin sebagai pendidik kurang memahami eksistensinya sebagai pemimpin berintegritas, sehingga berbagai kelemahan dialami dalam roda kepemimpinan yang dijalankan. Kedua, sebagai Pemimpin sebagai pendidik, seharusnya pemimpin mendidik orang-orang yang dipimpinnya, di mana pemimpin menjadi figure yang pantas untuk diteladani dalam segala aspek kehidupan; baik

1Myron Rush, Pemimpin Baru (Jakarta: Yayasan Pekabaran Injil "IMAMUEL", 1991), 32-33.

${ }^{2}$ Andre Bustanoby, Kepribadian Penunjang Pelayanan (Malang: Yayasan Penerbit Gandum Mas, 1995), 85. 
menyangkut aspek spiritual, moral, sosial, tindakan, pengalaman, gaya kepemimpinannya dan berbagai hal yang berhubungan dengan kinerja pelayanan sehingga orang-orang menjadi dewasa. Tetapi banyak pemimpin yang mau memimpin dan tidak semua pemimpin siap memimpin. Ketiga, tidak dapat disangkal bahwa pendewasaan merupakan tujuan dari pelayanan dan pengajaran sebagai pemimpin edukasi dan agen pendidikan Kristen. Sedangkan kedewasaan merupakan salah satu kebutuhan yang mendasar dalam kepemimpinan Kristen, tetapi sebuah pergumulan bahwa kedewasaan diri masih manjadi sorotan utama dalam sebuah lembaga dalam menjalankan tanggungjawab yang semuanya terkait dalam sebuah kepemimpinan.

\section{B. Prinsip Pemimpin Sebagai Pendidik}

Pemimpin sebagai pendidik memberikan tekanan pada pekerjaan seorang pemimpin sebagai pendidik, bukan saja sebagai pemberi makan, tetapi juga merawat, memelihara, dan mengasuh kawanan ternak. Jadi Pemimpin sebagai pendidik bukan suatu jabatan saja tetapi panggilan sebagai pendidik untuk yang melakukan pendidikan dan memimpin. Pemimpin sebagai pendidik adalah pemimpin yang sedang menjalankan kepemimpinannya sebagai pendidik dengan sasaran mendewasakan, yang dalam hal ini memiliki dua prinsip dasar yang perlu dipahami yaitu:

\section{Pemimpin Memberi Pengaruh}

Pemimpin harus memberikan penekanan pada model kepemimpinan untuk mempengaruhi orang lain agar mendapatkan pendukungnya. Jadi pemimpin bukan suatu kemampuan untuk mencapai kedudukan, melainkan bagaimana untuk mendapat pendukungnya. Dengan demikian orang yang mengejar kedudukan, pangkat dan jabatan bukanlah tujuan utama dan tidak salah berfikir bahwa sudah berhasil menjadi pemimpin. Inilah gambaran umum dari kebanyakan pemimpin, namun maxwell berpendapat bahwa pemimpin yang memiliki pengaruh adalah pemimpin sebaliknya tidak dapat disebut sebagai pemimpin apabila "pemimpin" tidak mempunyai pengaruh. Pengaruh menjadi langkah awal menurut Maxwell yaitu: "Investasi yang paling baik untuk untuk masa depan adalah pengaruh dan pengaruh adalah sebuah keahlian yang dapat dikembangkan oleh pemimpin. ${ }^{3}$

\section{Pemimpin: Seorang Pendidik}

Pemimpin sebagai pendidik merupakan kepemimpinan yang mendidik para pengikutnya, di mana pemimpin menjadi figure yang pantas untuk diteladani dalam segala aspek kehidupan; baik menyangkut aspek spiritual, moral, social, tindakan, pengalaman, gaya kepemimpinannya dan berbagai hal yang berhubungan dengan kinerja kepemimpinan. John MacArthur meringkas kepemimpinan berkaitan dengan pengaruh bahwa: "Pemimpin yang ideal adalah seorang yang memiliki hidup dan karakter yang dapat mendorong orang lain meneladaninya. Pemimpin yang baik adalah yang berwibawa, memiliki cara hidup yang benar dan layak untuk diteladani; bukan karena pemimpin punya kuasa dan punya gengsi, kepribadian atau jabatan tertentu."4 Selanjutnya Artur juga mendefinisikan kepemimpinan bahwa: "Menurut Kristus, jenis kepemimpinan yang paling sejati dan benar adalah yang mengutamakan pelayanan, pengorbanan dan sikap yang tidak mementingkan diri sendiri, jauh dari

3 Ibid.

${ }^{4}$ John MacArthur, Kitab Kepemimpinan, (Jakarta: BPK. Gunung Mulia, 2009), 9. 
citra pemimpin yang berdasarkan pada Kristus, tidak peduli seseorang itu memiliki kekuatan politik atau memegang wewenang kekuasaan yang besar." ${ }^{2}$ Penjelasan di atas memberikan pemahaman tentang prinsip pemimpin sebagai pendidik yang pantas untuk dieksplorasikan oleh pemimpin dalam hal memimpin dan sekaligus mendidik bawahannya.

\section{Dasar Pemimpin Sebagai Pendidik}

Pemimpin sebagai pendidik harus berdiri pada dasar teologis yang jelas dan kuat yaitu berdasarkan Perjanjian Lama dan Perjanjian Baru, sehingga memiliki warna Kristen yang jelas. Karena itu, konsep Pemimpin sebagai pendidik dasarnya dari Alkitab, maka akan terlihat dari nilai-nilai kebenaran yang terbangun dalam Perjanjian Lama maupun Perjanjian Baru yang kedunya mempunyai hubungan yang kuat.

\subsection{Perspektif Perjanjian Lama}

Prinsip dasar penciptaan Allah di taman Eden dan sepanjang sejarah bangsa Israel dalam Perjanjian Lama. Hal ini dijelaskan juga oleh Peter Wongso, bahwa:

Abraham yang berasal dari Ur-Kasdim yang kemudian menjadi Bapa semua orang beriman, juga akrab dengan profesi ini. Yakub, lelaki yang lahir di Kanaan yang kemudian menuntut hak kesulungannya untuk melayani Allah menjadi nenek moyang umat pilihanNya (Kejadian 29-33), ketika di rumah pamannya, ia menjadi seorang pemimpin yang bahkan mampu meneliti bagaimana memperoleh domba yang tumbuh dan kuat. ${ }^{6}$

Dalam Perjanjian Lama dijelaskan bahwa Tuhan adalah sebagai Pemimpin sebagai pendidik, pemimpin umat Israel (Yes. 40:11; Mzm. 23; Yeh. 34; Yer. 23:13). Di pihak lain, bangsa Israel selalu mengharapkan seorang pemimpin yang akan datang pada akhir zaman untuk mengPemimpin sebagai pendidikkan umat-Nya sebagai pengganti pemimpin yang setia pada misi Allah.

Seorang Pemimpin sebagai pendidik dalam Perjanjian Lama adalah raja Daud. "di dalam Alkitab 1 Samuel 16:11, di mana nyata bahwa Daud, sebelum ia menjadi raja adalah sebagai seorang Pemimpin sebagai pendidik."7 Maka tampak jelas bahwa Allah bermaksud melaksanakan pelayanan-Nya melalui orang-orang yang dipanggilNya untuk menuntun dan membimbing bangsa Israel yaitu tokoh-tokoh atau pemimpin bangsa Israel. Jadi konsep dalam Perjanjian Lama, Allah sering digambarkan sebagai Pemimpin sebagai pendidik dan juga melalui sejarah para pemimpin umat Israel (Yer. 23:1-4; Yeh. 34:1-31).

\subsection{Perspektif Perjanjian Baru}

Gambaran Pemimpin sebagai pendidik dalam Perjanjian Lama telah digenapi dalam Perjanjian Baru, karena dalam Perjanjian Baru Yesus yang disebut sebagai Pemimpin sebagai pendidik (Mat. 2:6, Yoh. 10:11-16). Seperti yang dijelaskan oleh Abineno, bahwa: "Janji itu digenapi oleh dan dalam Yesus Kristus ialah Pemimpin sebagai pendidik yang baik satu-satunya." 8 "Yesus adalah satu-satunya pemimpin

\footnotetext{
5 Ibid., viii.

${ }^{6}$ Peter Wongso, Obrolan Seorang Pemimpin sebagai pendidik (Malang: SAAT, 1995), 11.

${ }^{7}$ M. Bons Storm, Apakah Pengembalan Itu? (Jakarta: BPK Gunung Mulia, 1976), 16.

8 JL. Ch. Abineno, Penatua Jabatan dan Pekerjaannya (Jakarta: BPK Gunung Mulia, 1967), 15.
} 
yang legitimasi dan hal ini bukan saja dalam Injil Yohanis tetapi juga dalam seluruh Kitab Injil."9 Jadi Yesus sangat menjunjung tinggi tugas sebagai pemimpin yang melatih murid-muridNya, dengan memberikan teladan, dan pengajaran tentang pola pengPemimpin sebagai pendidikan (Matius 9:35-11:1; Lukas 10:1-20; Yohanes 1317).

Yesus dikatakan Pemimpin sebagai pendidik, karena bukan saja Dia mengenal domba-domba-Nya dan memberikan perhatian pada dombaNya, Dia juga datang untuk menunjukkan integritas-Nya bagi pengikut-Nya. Para Pemimpin sebagai pendidik juga digambarkan sebagai Pemimpin sebagai pendidik (Yoh. 21:15-19; I Ptr. 5:2-3; Kis. 20:28). Peter Wongso berkata: "Rasul Paulus juga menulis tiga pucuk surat yang khusus membicarakan prinsip-prinsip pengPemimpin sebagai pendidikan kepada domba-domba Tuhan yang masih muda yaitu I dan II Timotius dan Titus, yang sekarang disebut juga sebagai surat pengPemimpin sebagai pendidikan." 10 Maka dapat ditarik kesimpulan bahwa pemimpin sebagai pendidik dalam PB yang patut diteladani adalah Yesus Kristus langsung yang menjadi Pemimpin sekaligus mendidik para murid-muridNya.

\section{Tindakan Dasar Pemimpin Sebagai Pendidik}

Pada dasarnya, tindakan pemimpin sebagai pendidik dituntut mampu untuk melaksanakan fungsinya sebagai pemimpin yang mengarahkan, mendidik dan memberikan motivasi serta memberikan disiplin. Dan untuk mencapai semua itu, maka seorang pemimpin sebagai pendidik harus mampu memainkan perannya sebagai pemimpin yang mendidik dan sebagai pendidik yang memimpin.

\subsection{Pemimpin sebagai Pastor}

Pengembangan dari peran sebagai pastor adalah memperhatikan, membimbing, menuntun, dan memperhatikan setiap orang yang dipimpin (Mzm. 23; Yoh. 10:9). Seperti yang dijelaskan oleh Campbell, bahwa: "Pastoral care is the aspect of the ministry of the church which is concerned with the wellbeing of individual and of communities."11 Pemimpin sebagai pendidik atas domba-domba adalah salah satu fungsi yang sangat penting bagi pemimpin sebagai pendidik orang-orang yang dipimpin (Yoh. 21:15-17). "Karena di antara peranan pemimpin sebagai pendidik yang berarti seorang yang memelihara domba-domba atau pemelihara atau penjaga kawanan domba." 12 Yang dimaksud sebagai pemelihara adalah pemimpin sebagai pendidik harus mampu menyatakan kasihnya dan pengorbanannya kepada orang yang dipimpin. Atiyanto menjelaskan hal ini dalam buku demikian: "Salah satu sifat terpenting yang diberikan Allah kepada pemimpin Kristen Ialah kesanggupan untuk mengasihi semua orang."13 Bukan saja mengasihi orang yang baik, tetapi juga termasuk orang yang tidak membalas kasih, karena kasih Allah merupakan dasar bagi seorang pemimpin untuk melaksanakan tugasnya dengan benar.

Prinsipnya sebagai pastor adalah memberikat perhatian dan memberikan dorongan sehingga anggotanya merasa mendapatkan perhatian yang berharga dari pemimpinnya, hal itu merupakan sebuah proses edukasi dalam dunia kepemimpinan.

\footnotetext{
${ }^{9}$ Ibid., 103.

10 Wongso, Obrolan Seorang Pemimpin, 1.

11 Alastair V. Campbell. A Dictionary of Pastoral Care (Oxford: University Priting House, 1987),

12 J. Verkuyl, Panggilan dan Pekerjaan (Jakarta: BPK Gunung Mulia, 1954), 15.

${ }^{13}$ Sridari Atiyanto, Pengabdian Kristen (Bandung: Lembaga Literatur Baptis, 1986), 7.
} 188. 
Dengan perhatian inilah yang diharapkan bertumbuh secara sehat dalam kepemimpinan dan menjadi sarana dalam melaksanakan tugas sebagai pemimpin yang mendidik.

\subsection{Pemimpin sebagai Pembimbing}

Pengembangan peran pemimpin sebagai pembimbing lebih terfokus pada konselor. Peranan sebagai konselor sangat penting dalam pendewasaan, terkait dengan seorang Pemimpin yang akan membawa domba-dombanya ke air yang tenang, demikian ungkapan yang dikatakan dalam Mazmur 23. Pemimpin harus mampu membawa setiap orang yang dipimpinnya menuju kepada sebuah keadaan yang lebih baik, sama seperti ungkapan dalam Mazmur 23, yaitu "membawa mereka ke padang rumput yang hijau dan berair tenang supaya ternaknya dapat makan dengan puas dan minum tanpa merasa takut. Inilah peran Pemimpin sebagai pembimbing domba-dombanya." Membimbing berarti membantu orang yang berada dalam kebingungan untuk menentukan pilihan-pilihan yang pasti di antara berbagai pilihan, karena pilihan tersebut dipandang sebagai pilihan yang akan mempengaruhi keadaan jiwanya untuk masa sekarang dan masa yang akan datang.

Mencermati apa yang tertulis dalam Mazmur 23, Pemimpin sebagai pembimbing tidak akan pernah memilih-milih dombanya dengan mengkotakkotakkan, artinya hanya kelompok ini yang akan dibimbing ke air yang tenang dan padang rumput yang hijau. Tetapi semua domba akan dibawanya dan dibimbing untuk menikmati hidup dalam kebersamaan dengannya. Jay Adam berkata bahwa: "Pembimbing yang efektif, tidak dapat dilakukan tanpa pemimpin-Nya. Pemimpin dalam istilah rohani yaitu Pemimpin disebut "paraclete" yang artinya "pendamping" yang menggantikan Kristus bagi murid-murid-Nya."14 Oleh karenanya pemimpin sebagai pembimbing umat jangan pernah bersandar kepada pengertian dan kemampuan dirinya tetapi memberikan tempat kepada Roh Kudus untuk bekerja dalam kehidupan pribadinya dan orang-orang yang dibimbingnya.

"Salah satu nama Yesus dalam nubuat Yesaya adalah "The Woderful Counselor". Dunia saat ini tidak saja membutuhkan Juruselamat, tetapi juga konselor. Yesus adalah Penebus tetapi Dia membutuhkan agen-agen penebus."15 Demikian dikatakan oleh Julianto tentang motivasi pelayanan konseling. Istilah menyembuhkan sebenarnya mengacu kepada pribadi yang memiliki kuasa untuk menyembuhkan yaitu Yesus Kristus. Kesembuhan yang ajaib merupakan kebutuhan mendesak masyarakat sekarang ini, lihat saja animo masyarakat Indonesia ketika mendengarkan bahwa batu ajaib Ponari bisa menyembuhkan berbagai macam penyakit. Merekapun rela berdesak-desakan merelakan waktu menunggu giliran berhari-hari, tenaga bahkan harta untuk mendapatkan kesembuhan. Bagaimana dengan kesembuhan kekal yang Ajaib dan yang ada di dalam diri Yesus Kristus, apakah masyarakat gereja juga mempunyai animo yang besar terhadapnya? Hanya masalahnya adalah peran sebagai alat penyembuhan tidak ditekuni dengan serius dan dihidupi oleh kebanyakan Pemimpin sebagai pendidik bagi orang-orang yang dipimpin.

\subsection{Pemimpin sebagai Pengajar}

Peran Pemimpin sebagai pendidik yang lain adalah sebagai pengajar melalui ceramah, nasehat, motivasi dan peran ini boleh dikatakan sebagai yang rutin

${ }^{14}$ Jay E. Adam, Andapun Boleh Membimbing (Malang: Gandum Mas, 1986), 23.

${ }^{15}$ Simanjuntak, Perlengkapan Seorang Konselor, 13. 
dilakukan oleh banyak Pemimpin sebagai pendidik. Fungsi sebagai Pemimpin sebagai pendidik adalah nasehat, ajaran, motivasi dan dorongan-dorongan yang membangun melalui berita Firman Tuhan kepada setiap orang yang dipimpinnya. "Pemimpin akan menolong satu persatu untuk menyadari hubungannya dengan Allah dan mengajar orang untuk ketaatannya kepada Allah dan sesamanya."16 Dengan demikian Pemimpin sebagai pendidik harus mampu mengajar dengan baik dan benar, sehingga setiap orang yang dipimpin mengalami pertumbuhan dan kedewasaan secara pribadi.

Pelaksanaan pengajaran melalui nasehat, arahan dan berbagai model pengajaran merupakan alat dalam memberikan, petunjuk, dan teguran kepada setiap orang yang dipimpinnya. Dalam hal ini Atiyanto menjelaskan, bahwa: “...Pemimpin yang mengajar adalah abdi-abdi Allah." 17 Tuntutan bagi pelayan atau abdi Allah ini adalah dapat dipercayai (I Korintus 4:1) dan mengajar tentang berita dari Allah. Untuk itu, pemimpin diharapkan dapat membuktikan dan konsisten dengan apa yang diajarkan, sehingga merupakan kekuatan yang mendorong orang lain untuk meneladaninya sebagai bahagian dari displin dalam dunia kepemimpinan (I Timotius 2:12). Seperti yang dijelaskan juga oleh Oates, bahwa: "The New Testament writers expect of us as pastors, not only that we sure of our teaching and that the quality of our teaching be soud, but that we be capable of making the teachings come alive to our people."18 Oleh sebab itu secara teknis pengajaran seharusnya sesuai dengan kebutuhan dan menarik bagi pendengar yang dapat memberikan pertumbuhan bagi semua orang yang dipimpin.

\subsection{Pemimpin sebagai Evaluator}

Evaluasi merupakan alat untuk mengukur sejauh mana sebuah kegiatan pembelajaran di berhasil atau gagal. Sidjabat dalam bukunya menulis: "Kerapkali guru yang mengajar di gereja melalui program Sekolah Minggu, kegiatan pembinaan remaja, pemuda atau orang dewasa termasuk aktivitas katekisasi, enggan melaksakan evaluasi program atau kegiatan pembelajaran yang telah berlangsung."19 Mencermati apa yang diungkapkan di atas, pemimpin sebagai pendidik pun mengalami hal yang sama dan perlu dipahami bahwa keengganan untuk melaksanakan evaluasi biasanya disebabkan oleh beberapa hal: merasa tidak punya waktu atau tidak mau repot, menganggap bahwa evaluasi itu tidak perlu, memandang bahwa pekerjaan mengevaluasi adalah sebuah tugas menghakimi orang lain.

Memahami apa yang telah dikemukakan di atas, maka seluruh komponen pendidikan yang tidak salah jika dikenakan dalam sebuah sistem kepemimpinan yang perlu mendapatkan perhatian dalam melaksanakan evaluasi, seperti: pemimpin, orang yang dipimpin, lembaga atau organisasi, visi misi tujuan, setiap bisang tugas, cara pelaksanaan, sarana atau fasilitas dan waktu yang digunakan, kemudian goal yang telah dicapai. Di samping itu, unsur sikap, parasaan, kompetensi sosial dan kompetensi kerja harusnya juga mendapatkan perhatian dalam sebuah evaluasi. Dalam rangka menilai hasil kepemimpinan sehubungan dengan pemimpin sebagai pendidik dan pendidik sebagai pemimpin, Sidjabat memberikan beberapa petunjuk untuk dilakukan: Pertama, dengan mengajukan sejumlah pertanyaan secara lisan kepada setiap orang yang dipimpin. Kedua, melakukan wawancara. Ketiga, dengan

16 Strom, Apakah Pengembalaan Itu?, 15.

${ }^{17}$ Sridadi Atiyanto, Pengabdian Kristen (Bandung: lembaga Literatur Baptis, 1986), 6.

18 Wayne E. Oates. The Christian Pastor (Philadelphia: The Westminster Press, 1982), 120.

19 B. S. Sidjabat, Mengajar Secara Profesional (Bandung: Kalam Hidup, 2009), 335. 
memberikan sebuah angket ringkas untuk ditangani dan Keempat, pengamatan perubahan sikap dan prilaku. ${ }^{20}$ Peran seorang Pemimpin sebagai pendidik yang tidak kalah pentingnya adalah menjadi pemimpin yang berani mengadakan evaluasi bagi kinerjanya, dan itulah sesungguhnya pemimpin yang hebat.

Dapat disimpulkan bahwa tindakan penting yang harus dilakukan pemimpin sebagai pendidik yaitu harus mampu sebagai pastor, pembimbing, pengajar, dan evaluator. Jadi Pemimpin sebagai pendidik mempunyai tugas rangkap dalam pelayanan dan tunggung jawabnya dan sebagai pemimpin, yang ditekankan pendidik haurs bisa memberikan pengaruh positif, menjadi alat untuk mencapai kedewasaan rohani dan bisa mendidik orang yang dipimpinnya dalam pengajaran yang benar. Pemimpin sebagai pendidik dalam pelayanan bisa mempengaruhi untuk dewasa secara rohani melalui gaya hidup yang menjadi kesaksian, pelayanan ibadah, dengan perencanaan pelayanan yang jelas dan strategi dalam aplikasi pelayanan yang baik. Peran utama sebagai Pemimpin sebagai pendidik adalah sebagai pendidik, menjadi sumber pengajaran yang benar dan mampu memimpin setiap orang. Pada prinsipnya sebagai Pemimpin sebagai pendidik harus mempunyai visi yang jelas, langkah pencapaian visi yang baik, motivasi yang benar dihadapan Tuhan, melaksanakan tugas pelayanan dengan baik dan menjadi agen perubahan bagi SDM yang dipimpinnya menuju kepada sebuah lembaga atau organisasi yang maju.

\section{Kualitas Dasar Pemimpin sebagai Pendidik}

Tujuan Tuhan Yesus terhadap orang percaya yaitu diproses menuju kedewasaan, dengan tujuan untuk memuliakan Tuhan dan melakukan kehendak-Nya. Menjadi dewasa secara rohani merupakan proses yang harus dijalani oleh setiap orang Kristen yang percaya kepada Tuahn Yesus, selama ia hidup di muka bumi ini. Sedangkan yang menjadi ukuran kedewasaannya adalah sejauhmana ia memahami dan mengerti serta melaksanakan kebenaran firman Allah secara benar di dalam hidupnya. Proses pendewasaan warga gereja diuraikan sebagai berikut:

\subsection{Memahami Firman Tuhan dengan Benar}

Ceramah, nasehat dan motivasi yang didasarkan pada Firman Tuhan merupakan upaya yang signifikan terhadap proses pendewasaan bagi bawahan atau orang yang dipimpin. Untuk itu, pemimpin sebagai pendidik perlu memperlengkapi dirinya dengan pemahaman dan pengetahuan secara Alkitabiah, dan pemimpin yang jauh dari pemahaman Alkitab dalam kepemimpinannya, membuat kehidupan dan kepemimpinannya menjadi lemah dan tidak berdaya. Dalam setiap kondisi, kepemimpinan menghadapi banyak permasalahan sehingga pemimpin sendiri banyak yang mengalami frustasi dengan masalah yang tidak kunjung selesai. Pemimpin sebagai pendidik akan terus mengadakan terik-terik agar menuju kepada kedewasaan dan tanda-tanda orang yang dewasa adalah mereka terbuka kepada nasehat dan ajaran bahkan selalu meminta nasehat sebelum melaksanakan setiap tugas. Pengajaran berdasarkan firman Tuhan membawa dampak positif dalam mencapai kehendaki Tuhan bagi setiap orang yang percaya kepada-Nya.

Berkaitan dengan pengetahuan teologis yang ada hubungannya dengan pengalaman spitualitas dan kepribadian pemimpin akan berpengaruh pada setiap orang yang dipimpinnya. Orang-orang Kristen yang dewasa memiliki pengetahuan teologis, pengalaman spiritualitas dan kepribadian yang baik. Seseorang yang

20 Ibid, 336-337. 
memiliki pengatahuan teologis yang baik akan menjamin bahwa ia memiliki pengalaman mengenai pembentukan spiritualitas yang baik pula. Seseorang yang bertumbuh pengetahuan teologis dan pengetahuan spiritualitas akan menjamin bahwa ia memiliki pribadi yang memadai. Fakta ini mengindikasikan proses pendewasaan bahwa seseorang yang memiliki pengetahuan teologis yang memadai akan menjamin bahwa ia bertumbuh secara teologis dalam pengalaman spiritualitas dan memiliki pertumbuhan karakter dan perbuatan yang benar. Stevri dalam bukunya "Theologia dan Misiologi Reformed" mengemukakan sebagai berikut:

Seseorang yang memiliki formasi spiritualitas yang tinggi, kaya dengan nilai-nilai praktis dari pengalaman spiritualitasnya, seperti aktivitas rohani seperti berdoa, berpuasa, hidup saleh, berkarakter baik, namun tidak memilki pengetahuan teologis yang memadai, maka orang seperti ini pun, sesungguhnya belum memiliki formasi spiritualitas secara praktis. Begitu juga formasi spiritualitas, hanya dapat dikatakan pengalaman teologis, apabila digali dari pemahaman teologis. ${ }^{21}$

Lebih lanjut Stevri memaparkan, ada responden yang mengakui bahwa mereka tidak mengalami formasi spiritualitas. Pengetuan mereka tentang hubungan pengaruh doktrin terhadap formasi spiritualitas tidak menjadi pengalaman pribadi mereka. Dengan kata lain mereka membuat pertentangan ada jurang antara pengetahuan dengan pengalaman apa yang mereka ketahui tidak menjadi pengalaman, jelas itu bukanlah pengetahuan. ${ }^{22}$

Pertumbukan rohani yang terjadi dalam proses pendewasaan ialah pertumbuhan batiniah seseorang individu Kristen. Mekanisme pertumbuhan ini beranjak dari Allah yang terjadi dalam tanggungjawab manusia, dimana ia bertumbuh melalui pengalaman dan ujian, uang didalamnya seseorang belajar dari pengalaman atau peristiwa yang ia lalui dalam hidupnya. Yacob Tomatala dalam tulisannya menyatakan, pengetahuan yang dimiliki setiap orang merupakan dasar bagi suatu kepercayaan. ${ }^{23}$ Bertalian dengan indikasi proses pendewasaan setiap orang yang dipimpin maka, pertumbuhan pengetahuan teologis, pengalaman dan kepribadian merupakan faktor utama yang harus diperhitungkan sebagai gambaran dari pendewasaan setiap orang yang dipimpin untuk kepentingan pekerjaan pelayanan pembangunan tubuh Kristus dalam sebuah lembaga atau organisasi.

5.2 Model Hidup Yang Benar

Setiap orang yang dipimpin merupakan objek, sentralitas dalam upaya pendewasaan guna mencapai apa yang dikehendaki oleh Tuhan Yesus bagi orang percaya. Dalam Roma 11:36, sebab segala sesuatu adalah dari Dia, dan oleh Dia, dan kepada Dia; bagi Dialah kemuliaan sampai selama-lamanya. Dalam pendewasaan hidup, kedewasaan orang percaya terlihat dalam komitmennya untuk hidup mendeklarasikan kemuliaan Allah. Aspek ini tidak akan terpisah dari orang yang dewasa secara rohani. Orang yang dipimpin dalam sebuah lembaga atau organisasi merupakan umat yang telah dipisahkan dari dunia dan dikhususkan menjadi sebuah keluarga yang masuk dalam tanggung jawab untuk dipimpin oleh sang pemimpin. Sebutan ini menunjukkan kenyataan secara teologis bahwa mereka adalah yang kudus dan tidak dapat dinajiskan. Kerena itu, tanda kedewasaan mereka dalam seluruh aktivitasnya berkomitmen untuk hidup mendeklarasikan, atau harus

\footnotetext{
${ }^{21}$ Stevri I. Lumintang, Theologia dan Misiologia Reformed, Menuju Kepada Pemikiran Reformed dan Menjawab Keberatan (Batu: Departemen Literatur PPII, 2006), 261-262.

22 Ibid., 264.

23 Yakob Tomatala, Penatalayanan Gereja yang Efektif di Dunia Modern (Malang: Gandum Mas, 1993), 43.
} 
menyatakan kemuliaan Allah dan kekudusannya. Stevri dalam bukunya Theologia dan Misiologia Reformed, mengemukakan bahwa, tujuan utama hidup manusia berkaitan dengan tujuan penciptaan, penyataan, perjanjian dan pemilihan Allah, yaitu supaya manusia memuliakan Dia. Kemuliaan Allah menjadi dasar, tujuan utama dan tujuan akhir manusia adalah untuk menyatakan kemuliaan Allah. ${ }^{24}$ Jadi yang utama dalam hidup setiap orang percaya kepada Tuhan adalah menyatakan kemuliaan Allah. Bila setiap orang Kristen bertekad kuat untuk membina kehidupan rohaninya dan akhirnya menjadi seperti apa yang dikehendaki Tuhan bagi setiap orang percaya, maka gereja akan berisi orang-orang yang memiliki standar rohani yang kuat, sehingga dengan memiliki standar rohani yang kuat, karena berkomitmen untuk hidup serta mendeklarasikan kemuliaan Allah.

Kedewasaan setiap orang percaya (orang yang dipimpin) kepada Tuhan Yesus terlihat dari sikap dan tingkah lakunya yang lebih suka melayani dari pada dilayani. Melayani adalah tujuan Tuhan Yesus ke dunia ini, Yesus berkata: "Aku datang bukan untuk dilayani, tetapi untuk melayani. Yesus Guru Agung adalah teladan dalam hal melayani, Ia rela melayani orang-orang banyak. Dalam proses pendewasaan mereka, unsur terpenting yang menunjukkan bahwa seseorang menjadi dewasa ialah orang tersebut mempunyai sikap lebih suka melayani orang lain dari pada dilayani.

Memberi adalah bagian yang sekian lama dalam dasawarsa yang cukup rentang telah berjalan beriringan dengan usia manusia sampai detik ini. Topik tentang "memberi" telah terasa semakin penting dan sangat mendesak, secara khusus tatkala orang semakin gencar membicarakan topik seputar "Lebih berbahagia memberi dari pada menerima (Kis. 20: 35)." Persoalan memberi merupakan sebuah kata yang sering diperhadapkan kepada penulis ketika dalam pelayanan, tidak sedikit orang-orang kristen memberi pertanyaan tentang memberi, karena mereka belum memahami bagaimana memberi secara Alkitabiah. Jadi dalam hal ini kata "Suka memberi" bukanlah suatu hal yang baru lagi bagi setiap orang yang dewasa rohaninya di dalam Tuhan.

Merujuk kembali kepada uraian yang telah terbukti dalam perjalanan hidup setiap orang yang percaya kepada Tuhan Yesus. Mereka mengalami berkat kerajaan Allah yang disediakan bagi orang percaya. Dengan kata lain, jika seseorang hidup suka memberi, maka orang tersebut akan diberkati dengan berkat kerajaan Allah yang tidak ada putus-putusnya, ibarat sungai yang mengalir tak pernah berhenti. Inilah yang dikatakan indikasi proses pendewasaan mereka yakni suka memberi dari pada diberi atau menerima.

Indikasi proses pendewasaan orang yang dipimpin yang selanjutnya yaitu, berbuah dalam segala hal. Alkitab berkata hendaklah kamu berbuah di dlam Roh Kudus dan kebenaran. Setiap orang kristen yang percaya kepada Tuhan Yesus memiliki keinginan untuk bertumbuh secara rohani atau dewasa di dalam Tuhan. Rasul Paulus menulis kepada orang Galatia supaya orang yang dipimpin di Galatia mengalami pertumbuhan rohani dan pertumbuhan tersebut terbukti oleh buah-buah roh. Di sisi lain ketaatan merupakan buah Roh Kudus yang dialami oleh orang percaya melalui hubungan yang intim dengan Allah Galatia 5: 22-23. Orang Kristen yang dewasa memiliki tanda-tanda yang menyatakan bahwa mereka sudah dewasa adalah berbuah dalam segala hal. Hasil dari hubungan yang intim dengan Allah ialah semakin mengenal Allah ialah semakin mengenal Allah membuat semakin berbuah tidak tandus. Seperti yang telah dikemukakan di atas, kasih kepada Allah dan sesama

${ }^{24}$ Lumintang, Theologia dan Misiologia Reformed, 407. 
merupakan ciri atau tanda proses pendewasaan orang yang dipimpin. Dengan demikian dalam bagian ini diutarakan mengenai kasih kepada Allah dan sesama merupakan indikasi proses pendewasaan mereka. Untuk mengasihi orang lain terlebih dahulu seseorang mengetahui dan mengalami kasih Allah itu sendiri. Allah adalah kasih (1 Yohanes 4: 8). David Hocking mengutarakan bahwa, kasih berasal dari Dia, kasih-Nya sangat khusus dan melampaui segala jenis kasih.Kasih Allah tetap ada ketika semua kasih lainnya kehabisan.Ia tetap tinggal pada seseorang pada saat krisis atau sulit. Ia bertahan senantiasa dan sepenuhnya memuaskan. ${ }^{25}$ Masih merupakan kebutuhan mendasar dari setiap orang kristen yang sudah percaya kepada Tuhan Yesus. Kasih menunjukkan bahwa orang percaya itu bertumbuh menjadi dewasa. Jika seseorang mengetahui dan mengalami kasih Allah kepadanya, maka ia dapat mengasihi Allah dan sesama.

Alkitab banyak berbicara tentang kasih Allah yang diperlukan, namun dalam proses pendewasaan ternyata seseorang akan nampak ketika ia bertumbuh dalam kasih kepada Allah dan sesama, tidak mungkin membuktikan bahwa ia sudah bertumbuh menjadi dewasa secara rohani di dalam Tuhan, kenyataan ini menunjukkan bahwa tanpa memiliki kasih kepada Allah dan sesama, maka ia gagal menjalani proses pendewasaan secara rohani. Kasih kepada Allah ada dalam diri setiap orang yang mengetahui dan memahami serta mengalami pertumbuhan iman, ia pasti mengasihi Allah dan sesama.

\subsection{Pengalaman Hidup Bersama Tuhan}

Pengalaman hidup merupakan sebuah momen yang sangat berharga bagi setiap orang yang menghargainya. Kemudian pokok pembicaraan seputar Kekudusan merupakan kebutuhan yang mendasar bagi setiap orang percaya yang masih diizinkan Tuhan untuk hidup dalam dunia ini. Kata kunci dalam proses pendewasaan adalah kekudusan. Sifat Allah yang paling khas ialah kekudusan-Nya. Hanya Allah yang kudus. Kekudusan itu berarti bahwa Dia betul-betul murni dalam pikiran dan sikap. Donald dalam bukunya "Teologi perjanjia baru" menyatakan bahawa, "kekudusan inilah yang segrah merintangi pendekatan manusia kepada Allah, karena manusia menyadari ketidakkudusannya sendiri dihadapan Allah, dan sekalian menjadi ciri khas orang-orang dewasa rohaninya. ${ }^{26}$

Seorang pemimpin sekaligus sebagai pendidik, hendaknya menyadari bahwa salah satu hal penting dari pengalaman bersama Tuhan adalah kehidupan dalam kekudusan. Hidup dalam kekudusan merupakan sebuah pengalaman yang harus mewarnai kehidupan seorang pemimpin karena melalui kehidupan yang kudus, maka seorang pemimpin dapat memiliki hubungan yang intim dengan Tuhan, karena Tuhan berkata bahwa "kuduslah kamu sebab Aku kudus" (1 Petrus 1:16). Pengalaman hidup bersama Tuhan, dapat dirasakan secara khusus jika seorang pemimpin hidup dalam kekudusan, dan model kehidupan yang kudus menjadi salah satu dasar kuat bagi pemimpin untuk berperan sebagai pendidik yang dapat membentuk kehidupan orang-orang yang dipimpinnya.

Apakah mungkin Pemimpin sebagai pendidik orang yang dipimpin yang kurang yakin bahkan tidak yakin sama sekali akan keselamatan pribadinya di dalam Yesus Kristus? Hal semacam ini bisa saja terjadi walaupun intensitas kurang. Seth berkata bahwa: "Beberapa Pemimpin sebagai pendidik orang yang dipimpin tidak

25 David Hocking, Rahasia Keberhasilan Seorang Pemimpin (Yogyakarta: Yayasan Andi, 1994), 279.

${ }^{26}$ Donald Guthrie, Teologi Perjanjian Baru (Jakarta: BPK Gunung Mulia, 1995), 77. 
yakin akan keselamatannya."27 Hal ini sangat membahayakan bagi pelayanan Pemimpin sebagai pendidik dalam lembaga atau organisasi yang pimpinnya. Jadi meyakini akan keselamatan pribadi di dalam Yesus Kristus merupakan syarat mutlak yang harus dihidupi oleh Pemimpin sebagai pendidik orang yang dipimpin. Berkenaan dengan tugasnya sebagai Pemimpin sebagai pendidik, maka kabar yang akan disampaikan kepada orang yang dipimpin adalah kabar sukacita dan keselamatan di dalam Yesus.

Pengalaman keselamatan di dalam Yesus harus terlebih dahulu dialami oleh Pemimpin sebagai pendidik bagi orang-orang yang dipimpinnya, sehingga dengan demikian Pemimpin sebagai pendidik dapat memberitakan keselamatan itu kepada orang lain. Pemimpin sebagai pendidik juga akan berwibawa dan penuh keyakinan dalam memberitakan kabar keselamatan di dalam Yesus Kristus. Pemimpin sebagai pendidik orang yang dipimpin harus bisa menunjukkan jalan keselamatan itu kepada orang lain seperti yang dikatakan oleh Petrus dalam Kisah Para Rasul 4:12; "Dan keselamatan ada di dalam siapapun juga selain di dalam Dia, sebab dibawah kolong langit ini, tidak ada nama lain yang diberikan kepada manusia olehnya kita diselamatkan." Jadi dengan tegas diungkapkan dalam Alkitab bahwa keselamatan tidak ada di dalam siapapun selain di dalam Yesus. Pengalaman keselamatan Pemimpin sebagai pendidik membuat suatu keberanian untuk memberitahukan kepada orang lain agar benar-benar menjadikan kebenaran mutlak dalam melakukan tugas dan tanggungjawab. Umumnya Pemimpin sebagai pendidik yang tidak berdaya dan lemah dalam kepemimpinannya karena adanya beberapa hal mendasar dalam prilaku dan tindakannya; Pertama, tidak berani untuk berterus terang memberitakan kebenaran kekal. Kedua, banyak berspekulasi dan dalihan-dalihan yang berusaha membenarkan apa yang dilakukan dalam arti mencari kebenaran yang mendukung tindakan yang dilakukan. Ketiga, mencari keuntungan dalam setiap pelayanan yang dilakukan. Keempat, kehidupan pelayanan yang statis, tidak berkembang pada poros yang benar karena adanya pengaruh-pengaruh yang lebih dominan sehingga membuat sebuah model kepemimpinan dengan istilah "yang penting aman". Jadi sebagai pemimpin yang mendidik, harus memiliki keberanian yang didasarkan pada kualitas dasar yang dimiliki oleh seorang pemimpin sebagai pendidik, sehingga walaupun banyak tantangan yang dihadapi namun ada kekuatan dasar yang menjadi spirit dan kualitas yang terus mendorong seorang pemimpin untuk terus berlaku benar, tulus dan baik.

\section{Kesimpulan}

Pengaruh Pemimpin sebagai pendidik terhadap pendewasaan bagi setiap orang yang dipimpinnya berdampak besar, karena setiap bahawan akan menjadikan pemimpinnya sebagai patron atau ukuran dalam melakukan tanggungjawabnya. Pemimpin yang benar akan selalu mendidik dalam kebenaran dan memperlakukan setiap orang berdasarkan kebenaran, dan Pemimpin benar adalah pemimpin yang mendidik dan pendidik yang memimpin. Dalam setiap kepemimpinan akan selalu ada tantangan, cobaan, tekanan dan penolakan, namun jika dalam setiap prilaku dan tindakan seorang Pemimpin sebagai pendidik selalu berkomitmen melakukan kebenaran dan memperlakukan orang yang dipimpinnya berdasarkan kebenaran, maka sesungguhnya model kepemimpinan itulah yang kuat. Karena itu, setiap

27 Seth Msweli \& Donald Crider, Pemimpin sebagai Pendidik Sidang dan Pelayanannya (Bandung: Kalam Hidup, 1974), 11. 
pemimpin sebagai pendidik hendaknya memperhatikan beberapa hal di bawah ini yaitu:

Pertama, pembaharuan pemahaman atau pada pola pikir (mindset) Pemimpin sebagai pendidik yang dimulai dari kesediaannya untuk melihat kembali eksistensi perannya sebagai pendidik yang lebih terarah kepada sistem kepemimpinan pendidikan, artinya sebagai pemimpin harus memahami tugas yang sesungguhnya adalah mengajar untuk melakukan sesuai dengan Amanat Agung Yesus Kristus dalam Injil Matius 28:20 dengan kata akhir "ajarlah mereka", itu berarti bahwa dalam konteks sekarang dalam mengahadapi berbagai pergumulan dan tantangan dalam kepemimpinan lembaga atau organisasi, seorang pemimpin edukaktif harus mampu mendewasakan orang yang dipimpinnya melalui pendidikan dan pengajaran dengan menjadi seorang pemimpin yang edukatif dan sekaligus menjadi agen pelaksana pendidikan yang benar bagi semua orang.

Kedua, tujuan pelayanan (tugas dan tanggungjawab) seorang Pemimpin sebagai pendidik adalah memanusiakan manusia melalui model yang dilakukan Yesus yang adalah prototype manusia yang dikehendaki Allah. Seorang Pemimpin sebagai pendidik tidak cukup hanya mengajarkan kebenaran dengan perkataan, Ia harus dapat memperagakan kebenaran yang diajarkan. Inilah cara paling benar dan paling efektif dalam pelayanan. Itulah sebabnya dengan berani Paulus menyatakan bahwa dirinya dapat menjadi teladan (Flp. 3:17; 1Kor. 4:6,16; 2Tes. 3:7, 9 ). Tanpa peragaan kebenaran atau keteladanan yang riil, pelayanan hanya usaha mengelabui untuk keuntungan materi dan kepentingan pribadi lainnya.

\section{Daftar Pustaka}

Abineno, JL. Ch. Penatua Jabatan dan Pekerjaannya. Jakarta: BPK Gunung Mulia, 1967. Adam, Jay E. Anda pun Boleh Membimbing. Malang: Gandum Mas, 1986.

Atiyanto, Sridadi. Pengabdian Kristen. Bandung: Lembaga Literatur Baptis, 1986.

Bons Strom, M. Apakah Pengembalaan Itu? Jakarta: BPK Gunung Mulia, 1976.

Bustanoby, Andre, Kepribadian Penunjang Pelayanan. Malang: Yayasan Penerbit Gandum Mas, 1995.

Campbell, Alastair V. A Dictionary of Pastoral Care. Oxford: University Priting House, 1987.

Guthrie, Donald. Teologi Perjanjian Baru. Jakarta: BPK Gunung Mulia, 1995.

Hocking, David. Rahasia Keberhasilan Seorang Pemimpin. Yogyakarta: Yayasan Andi, 1994.

Lumintang, Stevri I. Theologia dan Misiologia Reformed: Menuju Kepada Pemikiran Reformed dan Menjawab Keberatan. Batu: Departemen Literatur PPII, 2006.

MacArthur, John. Kitab Kepemimpinan. Jakarta: BPK. Gunung Mulia, 2009.

Msweli, Seth dan Donald Crider. Pemimpin sebagai Pendidik Sidang dan Pelayanannya. Bandung: Kalam Hidup, 1974.

Oates, Wayne E. The Christian Pastor. Philadelphia: The Westminster Press, 1982.

Rush, Myron. Pemimpin Baru. Jakarta: Yayasan Pekabaran Injil "IMAMUEL", 1991.

Sidjabat, B. S. Mengajar Ssecara Profesional, Bandung: Kalam Hidup, 2009.

Simanjuntak, Julianto. Perlengkapan Seorang Konselor. Jakarta: LK3, 2007.

Sridari Atiyanto. Pengabdian Kristen. Bandung: Lembaga Literatur Baptis, 1986. 
Tomatala, Yakob. Penatalayanan Gereja yang Efektif di Dunia Modern. Malang: Gandum Mas, 1993.

Verkuyl, J. Panggilan dan Pekerjaan. Jakarta: BPK Gunung Mulia, 1954.

Wongso. Peter, Obrolan Seorang Pemimpin Sebagai Pendidik, Malang: SAAT, 1995. 